\title{
PENEGAKAN HUKUM TERHADAP PELAKU TINDAK PIDANA KORUPSI YANG MENJADI JUSTICE COLLABORATOR
}

\author{
Yulianus Marampa Rombeallo, Asher Tumbo \\ Universitas Kristen Indonesia Toraja, yrombeallo@ukitoraja.ac.id \\ Universitas Kristen Indonesia Paulus
}

\begin{abstract}
Abstrak
Justice Collaborator adalah pelaku yang bersedia menjadi saksi untuk membuka suatu kejelasan dari suatu tindak pidana teroganisir Tujuan penelitian ini adalah mengetahui peranan Justice Collaborator dalam pengungkapan Tindak Pidana Korupsi dan mengetahui kendala-kendala terkait Justice Collaborator dalam pengungkapan kasus tindak pidana korupsi. Penelitian ini menggunakan tipe penelitian yuridis normatif yang bersumberkan bahan primer dan sekunder serta tertier, serta tipe penelitian yuridis empiris yang dianalisis secara kualitatif dengan menguraikan secara deskriptif hasil data yang ada. Hasil penelitian menunjukkan Justice Collaborator bisa diterapkan dalam pengungkapan kejahatan korupsi yang sistematis, masif, dan terorganisir dimana pelaku bersedia untuk bekerja sama dengan penegak hukum dalam menemukan alat-alat bukti dari tersangka lain yang signifikan sehingga penyidikan dan pemeriksaan dapat berjalan dengan lancar. Maka dari itu perlindungan hukum terhadap justice collaborator menjadi sangat penting karena dikhawartikan akan adanya potensi ancaman dari pelaku lainnya, juga agar semua aturan terkait justice collaborator tidak saling tumpang tindih satu sama lain dan bisa menyatukan persepsi di antara para penegak hukum yang berakitan dengan kejahatan korupsi yang teroganisir.

Kata Kunci: Penegakan Hukum, Korupsi, Justice Collaborator
\end{abstract}

\begin{abstract}
Abstrack
Justice Collaborator is an actor who is willing to be a witness to open a clarity of an organized criminal act. Normative juridical sourced primary and secondary and tertiary materials, as well as the type of empirical juridical research which was analyzed qualitatively by describing descriptively the results of the existing data. To cooperate with law enforcement in finding evidence from other significant suspects so that investigations and examinations can run smoothly. Therefore, legal protection for justice collaborators is very important because it is feared that there will be potential threats from other actors, also so that all regulations related to justice collaborators do not overlap with each other and can unite perceptions among law enforcers related to corruption crimes organized.
\end{abstract}

Keywords: Law Enforcement, Corruption, Justice Collaborator.

\section{Pendahuluan}

Pembicaraan mengenai korupsi tidak pernah berhenti, karena pertumbuhan korupsi di Indonesia semakin meningkat baik kuantitas maupun kualitas.Dampak negatif dari korupsi dapat mengakibatkan berkurangnya kepercayaan terhadap pemerintah, berkurangnya kewibawaan pemerintah dalam masyarakat, menyusutnya pendapatan Negara,rapuhnya keamanan dan ketahanan Negara, 
perusakan mental pribadi dan hukum tidak lagi dihormati. ${ }^{1}$ Kata Korupsi berasal dari kata Latin "Corruptio" atau "Corruptus". Selanjtnya disebutkan bahwa "Corruptio" itu berasal pula dari kata asal 'Corrumper", suatu kata latin yang lebih tua. Dari bahasa Latin itulah turun ke banyak bahasa Eropa, seperti Inggris, yaitu corruption, corrupt; Prancis, yaitu corruption; dan Belanda, yaitu corruptie (Korruptie). Dari bahasa Belanda inilah kata itu turun ke bahasa Indonesia, yaitu 'Korupsi". ${ }^{2}$ Yang secara harafiah dari kata korupsi ialah kebusukan, keburukan, kebejatan, ketidakjujuran, dapat disuap, tidak bermoral, penyimpangan dari kesucian, katakata atau ucapan yang menghina atau memfitnah.

Pemberantasan korupsi harus dilakukan dengan berbagai upaya, baik pencegahan maupun penindakan. Pengorganisasian masyarakat, advokasi isu, maupun sosialisasi kebijakan anti korupsi merupakan hal yang tidak dapat dilepaskan dari upaya tersebut, termasuk dalam penegakan hukum. Lembaga peradilan merupakan salah satu ujung tombak pemberantasan korupsi, terutama dalam upaya penjeraan koruptor. Dalam persidangan perkara tentang tindak pidana korupsi yang masif diperlukan suatu terobosan untuk membuat terang perkara tersebut. Untuk dapat mengungkap pelaku tindak pidana korupsi yang mempunyai kedudukan ekonomi dan politik yang kuat tersebut tentunya membutuhkan keberanian dan saksi yang secara langsung mengetahui perbuatan tindak pidana korupsi tersebut. Saksi yang mengetahui secara langsung baik terlibat secara langsung di dalamnya atau tidak dan berani melaporkan kejadian tersebut disebut whistle blower dan Justice Collaborator. Justice Collaborator dapat disebut juga sebagai pembocor rahasia atau peniup pluit yang mau bekerjasama dengan aparat penegak hukum atau partisipant whistle blower. Si pembocor rahasia haruslah orang yang ada di dalam organisasi yang dapat saja terlibat atau tidak terlibat didalam tindak pidana yang dilaporkan itu. ${ }^{3}$

Istilah whistle blower dan Justice Collaborator juga keduanya terdapat dalam Surat Edaran Mahkamah Agung (SEMA) Nomor 4 Tahun 2011 tentang Perlakuan Bagi Pelapor Tindak Pidana (Whistle Blower) dan Saksi Pelaku yang Bekerjasama (Justice Collaborator) di dalam Perkara Tindak Pidana Tertentu. Justice collaborator adalah saksi yang juga pelaku dari sebuah kejahatan, yang bertujuan untuk memudahkan pembuktian dan penuntutan serta dapat mengungkap tuntas suatu tindak pidana terutama yang berkaitan dengan organisasi kejahatan. Dalam Kitab Undang-Undang Hukum Acara Pidana (KUHAP) belum mengatur ketentuan Justice Collaborator, kecuali UU Nomor 13 Tahun 2006 jo Undang-Undang Nomor 31 Tahun 2014 Tentang Perubahan Atas Undang-Undang Nomor 13 Tahun 2006 yang hanya menfokuskan perlindungan saksi dan korban, Undang-Undang ini pun tidak memberikan "hak istimewa" kepada seorang Justice Collaborator.

Seorang saksi dapat dikatakan sebagai Justice Collaborator apabila informasi yang diberikan oleh saksi tersebut sangatlah signifikan dalam mengungkap kasus/perkara yang selama ini sulit diungkap, dengan itikad yang sunguh-sunguh

\footnotetext{
${ }^{1}$ Cahaya, Suhandi \& Surachmin,2011, Strategi dan Teknik Korupsi Mengetahui Untuk Mencegah, Sinar Grafika, Jakarta, hlm.85-86

${ }^{2}$ Hamzah, Andi, 2004, Hukum Acara Pidana Indonesia Edisi Revisi, Sinar Grafika, Jakarta, hlm. 17

${ }^{3}$ Wijaya, Firman, 2012, Whistle Blower dan Justice Collaborator Dalam Perpektif Hukum, Penaku, Jakarta, hlm. 57
} 
bertobat sepenuhnya dan mengikuti perintah penegak hukum. Pentingnya peranan saksi pelaku (Justice Collaborator) merupakan kunci untuk memperoleh kebenaran materil. Karena saksi merupakan orang yang keterangannya bisa menentukan keputusan hakim dalam mengambil keputusan. Keberadaan Justice collaborator tentu saja akan membawa dampak yang sangat besar dalam mencari dan menemukan "dader intellectual" dalam suatu perkara pidana. Dengan latar belakang yang diuraikan maka latar belakang yang akan diteliti adalah Bagaimanakah peranan Justice Collaborator dalam pengungkapan kasus Tindak Pidana Korupsi Apakah kendala-kendala terkait Justice Collaborator dalam pengungkapan kasus Tindak Pidana Korupsi.

\section{Metode}

Tipe penelitian yang digunakan dalam penulisan ini pada dasarnya bersifat yuridis normatif cara yang dipergunakan di dalam penelitian hukum yang dilakukan dengan cara meneliti bahan pustaka. ${ }^{4}$ Penelitian hukum yang meletakkan hukum sebagai sebuah bangunan sistem norma disebut penelitian hukum normatif. Sistem norma tersebut antara lain mengenai asas-asas, doktrin (ajaran), norma, kaidah dari peraturan perundangan, perjanjian serta putusan pengadilan. 5 Sehubungan dengan data yang diperlakukan dalam penelitian ini, penulis mengambil data dari internet terkait kasus Justice Collaborator dalam mengungkap tindak pidana korupsi. Data yang diperoleh dalam penelitian ini di analisis secara Kualitatif Deskriptif.

\section{Peranan Justice Collaborator dalam mengungkap kasus Tindak Pidana Korupsi}

Korupsi yang sampai pada saat ini sudah sangat meresahkan dan membuat situasi di negara kita menjadi sangat memprihatinkan, dampak yang bisa ditimbulkan akan berdampak langsung kepada kesejahteraan masyarakat. Semakin hari tindak pidana ini terus berkembang, pihak-pihak yang terlibat dalam kejahatan ini biasa dilakukan oleh orang-orang yang terpandang, berpendidikan tinggi, memiliki jabatan dan kedudukan penting dalam institusi negara. Hal ini menunjukkan bahwa korupsi biasa dilakukan oleh orang-orang yang cerdas, cermat,dan orang-orang yang mengerti seluk-beluk keuangan dan birokrasi dalam institusinya tersebut. Untuk menutupi perbuatannya, para pelaku cenderung akan membuat sebuah skenario yang rapi dan sulit diidentifikasi oleh penyidik dan kejaksaan sehingga mempersulit proses pemeriksaan di persidangan.

Kerugian negara akibat maraknya tindak pidana korupsi ini pun tidak dapat dibilang kecil, disini tentu negaralah yang paling dirugikan sehingga berimbas pada masyarakat yang mana segala pembangunan dan infrastruktur dibiayai oleh negara. Masyakarat menjadi semakin menderita dengan banyaknya tindak pidana korupsi ini.

\footnotetext{
4 Soekanto, Soerjono \& Sri Mamudji, 2009, Penelitian Hukum Normatif Suatu Tinjauan Singkat, PT.Raja Grafindo Persada, Jakarta, hlm. 13

5 Fajar, Mukti dan Yulianto,2017, Dualisme Penelitian Hukum Normatif dan Empiris, Pustaka Pelajar, Yogyakarta, hlm. 33
} 
Kejahatan yang terorganisir seperti tindak pidana korupsi haruslah diberantas dengan tindakan-tindakan yang tepat. Apabila para penegak hukum kekurangan akal dan kurang cermat untuk memberantas semua ini, maka tidak heran korupsi akan semakin berkembang dan merajalela, para koruptor pun semakin mudah untuk menghilangkan uang negara tanpa jejak. Dalam Pembuktian Tindak Pidana Korupsi yang masif dan teroganisir tersebut itulah maka dibutuhkan indikator utama yang dapat membongkar kejahatan tersebut salah satu yang dapat digunakan dalam kualifikasi alat bukti adalah alat bukti keterangan saksi yang merupakan alat bukti yang paling utama dalam perkara pidana. Hampir semua pembuktian perkara pidana, selalu didasarkan kepada pemeriksaan keterangan saksi sekurang-kurangnya di samping pembuktian dengan alat bukti yang lain, masih tetap selalu diperlukan pembuktian dengan alat bukti keterangan saksi. ${ }^{6}$

Keterangan saksi yang dapat bisa digunakan untuk memperjelas penyelesaian kasus korupsi adalah keterangan saksi yang menjadi justice collaborator dimana aparat hukum akan mengajak pelaku kejahatan untuk bekerjasama menyelesaikan kasus korupsi yang sedang ditangani dimana para aktor pelaku korupsi itu sendiri yang akan "bercerita" tentang keseluruhan aksi korupsi yang dilakukan oleh komplotannya. Dan mengenai perlindungannya dimulai sejak tingkat penyidikan dan harus diberikan jaminan bahwa pada saat dan setelah memberikan keterangan tetap dalam keadaan bebas dari ancaman atau tekanan yang mengakibatkan berkurangnya saksi memberikan keterangan secara bebas sehingga keterangan tidak memilki nilai originalitas keterangan saksi yang dibutuhkan dalam pembuktian perkara yang sedang diperiksa. ${ }^{7}$

Undang-Undang Nomor 31 Tahun 2014 tentang Perlindungan Saksi dan Korban merupakan kebijakan hukum pidana (penal policy) yang sudah sangat tepat mengingat untuk suatu pembuktian tindak pidana yang dilakukan dengan modus operandi sistematis dan terorganisir. Tugas yang dirasakan berat oleh Penuntut Umum atau Polisi jika dalam suatu tindak pidana sangat sulit untuk mengumpulkan alat bukti berupa saksi yang melihat sendiri, mendengar sendiri atau mengalami sendiri suatu tindak pidana bahwa pelaku melakukannya dengan terorganisasi. ${ }^{8}$

Berdasarkan SEMA No.4 Tahun 2011 ,untuk dapat disebut sebagai Justice Collaborator, yang bersangkutan haruslah :

1. Merupakan salah satu pelaku tindak pidana tertentu sebagaimana dimaksud dalam SEMA No.4 Tahun 2011, yaitu tindak pidana korupsi, terorisme, narkotika, pencucian uang, perdagangan orang, dan lain-lain, namun bukan pelaku utama dalam kejahatan tersebut;

2. Mengakui kejahatan yang dilakukannya; dan

3. Memberikan keterangannya sebagai saksi di dalam proses peradilan.

\footnotetext{
6 Yarahap, M. Yahya, 2009, Pembahasan Permasalahan dan Penerapan KUHAP (Pemeriksaan Sidang Pengadilan, Banding, Kasasi, dan Peninjauan Kembali), :Sinar Grafika, Jakarta, hlm. 319

7 Mahkamah Agung Republik Indonesia,2015, Kompilasi Penerapan Hukum Oleh Hakim dan Strategi Pemberantasan Korupsi, Biro Hukum dari Humas Badan Urusan Administrasi Republik Indonesia, hml. 115

8 Imam Thurmudhi, Tesis, Perlindungan Hukum Terhadap Whistle Blower Kasus Korupsi Berdasarkan UndangUndang Nomor 13 Tahun 2006 Tentang Perlindungan Saksi dan Korban (Studi Kasus Susno Duadji), Program Studi Magister (S2) Ilmu Hukum Universitas Indonesia, hlm. 60
} 
Menurut hakim sesuai Surat Edaran Mahkamah Agung No 4 Tahun 2011 ada beberapa pedoman untuk menentukan seseorang sebagai Justice Collaborator, yaitu merupakan salah satu pelaku tindak pidana tertentu, mengakui kejahatan yang dilakukannya, bukan pelaku utama dalam kejahatan tersebut, serta memberikan keterangan sebagai saksi di dalam proses peradilan. Bagi hakim, pelaku utama tidak layak menjadi Justice Collaborator. Hukuman yang dapat diberikan hakim terhadap Justice Collaborator adalah menjatuhkan pidana percobaan bersyarat khusus atau menjatuhkan pidana berupa pidana penjara yang paling ringan di antara terdakwa lainnya yang terbukti bersalah dalam perkara dimaksud. Posisi Justice Collaborator sangat relevan bagi sistem peradilan pidana Indonesia untuk mengatasi kemacetan prosedural dalam pengungkapan suatu kejahatan terorganisir dan sulit pembuktiannya. Membantu aparat penegak hukum dalam menemukan alat-alat bukti dan tersangka lain yang signifikan. Justice Collaborator adalah langkah strategis untuk mempercepat pengungkapan tindak pidana terorganisir seperti tindak pidana korupsi.

Keberadaan Justice Collaborator sangat potensial membantu aparat penegak hukum dalam menemukan alat-alat bukti dan tersangka lain yang signifikan sehingga penyidikan dan pemeriksaan dapat berjalan efektif karena dia adalah orang yang pernah terlibat dalam organisasi kejahatan dan telah melakukan suatu tindak pidana.

\section{Kendala-kendala Terkait Justice Collaborator dalam Mengungkap Tindak Pidana Korupsi}

Justice collaborator memiliki peranan yang sangat dominan dan strategis dalam membantu aparat penegak hukum untuk membongkar dan mengungkap tindak pidana. Hal itu dikarenakan, seorang Justice Collaborator adalah orang yang ikut berperan dalam terjadinya suatu tindak pidana terorganisir dan dilakukan secara berjamaah seperti tindak pidana korupsi. Namun posisi seorang Justice Collaborator bukan merupakan pelaku utama dari terjadinya suatu tindak pidana korupsi. Orang yang demikian tersebut dapat dijadikan sumber informasi dalam kaitannya dengan adanya tersangka dan alat bukti lain dalam tindak pidana korupsi yang belum ditemukan oleh penegak hukum. Salah satu persoalan upaya pemberantasan tindak pidana korupsi adalah masalah penegakan hukum (law enforcement), khususnya proses peradilan. UN Anti-Corruption toolkit menyebutkan While the development of the convention reflects the recognition that efforts to control corruption must go beyond the criminal law, criminal justice measures are still clearly a major element of the package. ${ }^{9}$

Jadi, ada pengakuan bahwa pengadilan korupsi harus melampaui hukum pidana dan langkah-langkah atau tindakan peradilan pidana jelas masih merupakan elemen utama dari paket. Langkah-langkah atau tindakan tersebut, juga banyak disebabkan oleh penghalangan proses peradilan yang di dalam dalam praktik peradilan di Indonesia aparat hukum seringkali menemukan berbagai kendala yuridis dan non-yuridis untuk mengungkap tuntas dan menemukan kejelasan suatu tindak pidana, terutama menghadirkan saksi-saksi kunci dalam proses hukum sejak

\footnotetext{
${ }^{9}$ Un-Anti Corruption Toolkit. 2004, The Global Programme against Corruption Third-Edition.Vienna:the United nations Anti-Corruption hlm.28
} 
penyidikan sampai proses pengadilan. Kendala non yuridis, yaitu Orang enggan menjadi Justice Collaborator karena masalah ketakutan, menjadi Justice Collaborator beresiko amat berbahaya adanya ancaman yang nyata atau kekhawatiran akan adanya ancaman, baik secara fisik maupun psikis akibat pengungkapan yang dilakukannya. Dan para pelaku kejahatan mempunyai loyalitas yang tinggi antara para pelaku yang dikenal dengan "kesaksian diam atau sumpah diam (omerta), yaitu suatu komitmen dan aturan yang tidak tertulis diantara anggota mafia yang tidak mudah digoyahkan". Pelanggaran atas omerta tersebut adalah nyawa tebusannya bagi siapapun yang melanggarnya. Oleh sebab itu Perlindungan hukum dan perlindungan khusus terhadap pelaku yang bekerja sama merupakan salah satu strategi utama dalam pengungkapan dan penanganan Kejahatan tindak pidana korupsi secara efektif.

Berdasarkan penjabaran diatas sangatlah patut adanya perlindungan hukum bagi Justice Collaborator dalam mengungkap fakta tindak pidana korupsi di Indonesia. Terhadap orang-orang yang kritis dan berani mencegah dan mengungkap korupsi yang telah ia lakukan bersama rekan-rekannya. Namun upaya perlindungan yang dilakukan terhadap Justice Collaborator juga masih mengalami sejumlah kendala.hambatan dalam perlindungan hukum terhadap Justice Collaborator, yaitu belum adanya dasar hukum yang kuat untuk menjamin perlindungan terhadap Justice Collaborator.

Sedangkan untuk kendala yuridisnya pengaturan mengenai justice collaborator dalam peraturan perundang-undangan masih bersifat singkat, dan terbagi-bagi sebagaimana selintas terlihat dalam :

1. Undang-Undang Nomor 13 Tahun 2006 jo Undang-Undang Nomor 31 Tahun 2014 tentang perlindungan saksi dan korban.

2. Undang-Undang Nomor 31 Tahun 1999 jo Undang-Undang Nomor 20 Tahun 2001 tentang Pemberantasan Tindak Pidana Korupsi,

3. Undang-Undang Nomor 8 Tahun 2010 tentang pencegahan dan pemberantasan Tindak Pidana Pencucian Uang.

4. Undang-Undang Nomor 30 Tahun 2002 tentang Komisi Pemberantasan Tindak Pidana Korupsi.

5. PP Nomor 57 Tahun 2003 tentang Perlindungan Khusus Pelapor dan Saksi.

Dari kajian prespektif kendala peraturan perundang-undangan hendaknya dibuat peraturan yang mengatur tentang Justice Collaborator secara tersendiri dan bersifat integral agar tidak ada saling tumpang tindih dalam menentukan perlindungan hukum bagi pelaku yang menjadi justice collaborator.

Hal lain yang menghambat adalah adanya ketidaksamaan pandangan dengan hakim yang memeriksa perkara korupsi yang menolak penetapan seorang terdakwa menjadi Justice Collaborator meskipun sudah disetujui dan diusulkan oleh Komisi Pemberantasan Tindak Pidana Korupsi. Cara pandang hakim, jaksa, LPSK atas pelaku bekerja sama yang berbeda-beda inilah yang mengakibatkan reward atas pelaku yang bekerja sama sulit didapatkan. Ini juga akibat kurang harmonisnya peraturan soal pelaku yang bekerja sama, misalnya dalam revisi Undang-undang Nomor 31 Tahun 2014 tentang perlindungan saksi dan korban juga tidak memasukkan mengenai persyaratan sebagai pelaku yang bekerja sama sehingga rumusan syarat ini harus dicari padanannya dalam beberapa peraturan di luar UU. 
Misalnya Surat Edaran Mahakama Agung Nomor 14 Tahun 2011 atau kesepakatan antar lembaga, yaitu Peraturan Bersama Menteri Hukum dan Hak Asasi Manusia Republik Indonesia, Jaksa Agung Republik Indonesia, Kepala Kepolisian Negara Republik Indonesia, Komisi Pemberantasan Korupsi Republik Indonesia, dan Ketua Lembaga Perlindungan Saksi dan Korban Republik Indonesia tentang Perlindungan Bagi Pelapor, Saksi Pelapor dan Saksi Pelaku yang Bekerjasama. Inilah yang membuka celah beda pandangan tersebut.salah satu faktor penghambat dalam pelaksanaan pemberian perlindungan bagi Justice Collaborator selama ini.

\section{Kesimpulan}

Berdasarkan uraian hasil penelitian pada bab-bab sebelumnya mengenai adanya Justice Collaborator dalam pengungkapan tindak pidana korupsi maka dapat disimpulkan hal-hal sebagai berikut :

1. Justice Collaborator adalah seorang yang merupakan salah satu pelaku tindak pidana yang bukan pelaku utama, yang ikut berperan dalam terjadinya suatu tindak pidana terorganisir seperti tindak pidana korupsi. Dimana pelaku ini bersedia untuk bekerjasama dengan penegak hukum untuk membantu aparat penegak hukum dalam menemukan alat-alat bukti dan tersangka lain yang signifikan sehingga penyidikan dan pemeriksaan dapat berjalan efektif. Posisi Justice Collaborator sangat relevan bagi sistem peradilan pidana Indonesia untuk mengatasi kemacetan prosedural dalam pengungkapan suatu kejahatan terorganisir dan sulit pembuktiannya serta memudahkan pembuktian dan penuntutan serta dapat mengungkap tuntas suatu tindak pidana terutama yang berkaitan dengan tindak pidana terorganisir seperti tindak pidana korupsi.

2. Dalam praktik peradilan, aparat hukum seringkali menemukan berbagai kendala atau hambatan-hambatan non yuridis dan yuridis untuk mengungkap tuntas dan menemukan kejelasan suatu tindak pidana. Kendala non yuridis yang dimaksud, yaitu dimana Orang enggan menjadi Justice Collaborator karena masalah ketakutan, beresiko amat berbahaya adanya ancaman yang nyata atau kekhawatiran akan adanya ancaman, baik secara fisik maupun psikis. Kemudian para pelaku kejahatan mempunyai loyalitas yang tinggi antara para pelaku suatu komitmen dan aturan yang tidak tertulis diantara anggota mafia yang tidak mudah digoyahkan. Sedangkan hambatan yuridis adalah belum adanya dasar hukum yang kuat untuk menjamin perlindungan terhadap Justice Collaborator, dimana dalam hukum positif Indonesia, belum diatur secara keseluruhan tentang peraturan perundang-undangan yang mengatur secara khusus sebagai pedoman Justice Collaborator dalam mengungkap fakta tindak pidana korupsi hal yang lain menghambat adalah adanya ketidaksamaan pandangan dengan hakim yang memeriksa perkara korupsi yang menolak penetapan seorang terdakwa menjadi Justice Collaborator meskipun sudah disetujui oleh Komisi Pemberantasan Tindak Pidana Korupsi (KPK).

\section{Referensi}

Cahaya, Suhandi \& Surachmin, 2011. Strategi dan Teknik Korupsi Mengetahui Untuk Mencegah, Sinar Grafika, Jakarta. 
Fajar, Mukti \& Yulianto, 2017. Dualisme Penelitian Hukum Normatif dan Empiris, Pustaka Pelajar, Yogyakarta.

Hamzah, Andi, 2004. Hukum Acara Pidana Indonesia Edisi Revisi, Sinar Grafika, Jakarta.

Imam Thurmudhi, Tesis, Perlindungan Hukum Terhadap Whistle Blower Kasus Korupsi Berdasarkan Undang-Undang Nomor 13 Tahun 2006 Tentang Perlindungan Saksi dan Korban (Studi Kasus Susno Duadji), Program Studi Magister (S2) Ilmu Hukum Universitas Indonesia.

Mahkamah Agung Republik Indonesia, 2015. Kompilasi Penerapan Hukum Oleh Hakim dan Strategi Pemberantasan Korupsi, Biro Hukum dari Humas Badan Urusan Administrasi Republik Indonesia.

Soekanto, Soerjono \& Sri Mamudji, 2009. Penelitian Hukum Normatif Suatu Tinjauan Singkat, PT. Raja Grafindo Persada, Jakarta.

Un-Anti Corruption Toolkit. 2004. The Global Programme against Corruption, ThirdEdition.Vienna: The United Nations Anti-Corruption.

Wijaya, Firman,2012, Whistle Blower dan Justice Collaborator Dalam Perpektif Hukum, Penaku, Jakarta.

Yarahap, M. Yahya, 2009, Pembahasan Permasalahan dan Penerapan KUHAP (Pemeriksaan Sidang Pengadilan, Banding, Kasasi, dan Peninjauan Kembali), Sinar Grafika, Jakarta. 